\title{
Antioxidant, Antidiabetic, and Anti-Inflammatory Effects of Extracts and Fractions from Parthenocissus tricuspidata Stems
}

\author{
Eun Kyung Cho and Young Ju Choi*
}

Department of Food and Nutrition, College of Medical Life Sciences, Silla University, Busan 617-736, Korea

Received January 25, 2013 /Revised February 18, 2013 /Accepted March 25, 2013

\begin{abstract}
This study was carried out to analyze the effects on antioxidative, antidiabetic, and anti-inflammatory activities of Parthenocissus tricuspidata (PT) stem extracts. The total phenolic contents of hot water and ethanol extracts from PT stems were $61.5 \mathrm{mg} \mathrm{TAE} / \mathrm{g}$ and $122.1 \mathrm{mg} \mathrm{TAE} / \mathrm{g}$, respectively. The antioxidative activities of hot water and ethanol extracts from PT stem were measured by using 1,1-diphenyl-2-picrylhydrazyl (DPPH) radical scavenging activity and superoxide dismutase (SOD) assay. The DPPH radical scavenging activities of ethanol extract and butanol fraction were approximately $95 \%$ and $92 \%$ at $1 \mathrm{mg} / \mathrm{ml}$, respectively, and the SOD activities of ethanol extract and butanol fraction were about $91 \%$ and $97 \%$ at $1 \mathrm{mg} / \mathrm{ml}$, respectively. The DPPH radical scavenging and SOD activities of ethanol extract and butanol fraction from PT stem increased remarkably increased in a dose-dependent manner and were higher than in the hot water extracts. Compared to the acarbose, a known anti-diabetic drug, which was used as a positive control, the a-glucosidase inhibitory capacity of PT stem showed a strong inhibitory rate in ethanol extract and in butanol and hexane fractions. We investigated the effect of hot water extract from PT stem on lipopolysaccharide (LPS)-induced nitric oxide (NO) production in RAW 264.7 cells. Hot water extract from PT stem inhibited LPS-induced NO production up to $40 \%$ at a treatment of $1 \mathrm{mg} / \mathrm{ml}$. These results suggest that PT stem extracts have an effect on antioxidative, antidiabetic, and anti-inflammatory activities and thus have great potential as antidiabetic materials and a source for natural health products.
\end{abstract}

Key words : Parthenocissus tricuspidata, antioxidative activity, a-Glucosidase, nitric oxide

\section{서 론}

당뇨병은 삶의 질을 떨어뜨리는 1 위 질환으로서 전세계인 구의 $3 \%$ 가 당뇨병으로 고통 받고 있으며, 국내에서도 당뇨병 및 당뇨병 합병증으로 인한 사망률이 전체 사인의 네 번째를 차지하는 것으로 보고되고 있다[1]. 최근의 식생활의 서구화로 인한 비만인구의 증가로 당뇨병 환자가 매년 $10 \%$ 이상 증가하 고 있으며, 당뇨병은 유전이나 대사적 요인 등에 의하여 췌장 B-cell에서의 인슐린 분비장애와 조직에서의 인슐린 저항성 등 으로 발병되며 고혈당이 주요 증상이다[34].

혈당 수준의 증가는 ROS의 발생과 관련되어 있으며 고혈당 은 췌장의 B-cell을 포함한 기관의 산화적 스트레스에 기인하 는 것으로 보고되고 있다[26]. ROS 발생과 산화적 스트레스는 B-cell 손상은 당뇨병 환자에 있어서 동맥경화증이나 신경병증 과 같은 합병증 유발과 관계되어 있으며[20], 또한 산화적 스트

\footnotetext{
*Corresponding author

Tel : +82-51-999-5459, Fax : +82-51-999-6959

E-mail : yjchoi@silla.ac.kr

This is an Open-Access article distributed under the terms of the Creative Commons Attribution Non-Commercial License (http://creativecommons.org/licenses/by-nc/3.0) which permits unrestricted non-commercial use, distribution, and reproduction in any medium, provided the original work is properly cited.
}

레스의 증가는 인슐린 분비를 감소시키는 원인으로 알려져 있다[29]. 당뇨병은 혈관장애, 신경병증, 급·만성감염 등 고혈 당 상태가 장기간 지속됨에 따라 심각한 만성합병증을 일으키 는 대사성질환으로 발병률도 급격히 증가할 뿐만 아니라 유병 연령이 점차 낮아지고 있어 그 심각성이 대두되고 있다[5].

우리나라 대부분의 성인당뇨병은 비만으로 발병되는 인슐 린 비의존형(제2형 당뇨)환자가 대부분을 차지하는 것으로 보 고되고 있으며[19], 당뇨병의 치료는 대부분 약물치료, 식이요 법과 운동요법에 의존하고 있으며, 약물복용에 따른 독성문제 와 환자의 내성문제 등 많은 부작용이 대두되고 있다. 현재 시판되고 있는 acarbose나 voglibose 등의 a-glucosidase 저해 제가 시판되고 있으나 이들 약제를 장기간 복용할 경우 일부 환자에 있어서 복부팽만감, 구토, 설사 등 부작용이 나타날 수 있어 그 사용이 제한될 수 있다[3, 13, 32].

이러한 부작용을 줄이고 식후 혈당강화 효과를 가지는 천연 물에 대한 관심이 높아지면서 새로운 a-glucosidase나 aamylase 저해물질을 찾는 연구가 꾸준히 진행되고 있다. 최근 천연물에 대한 관심이 증대되면서 항당뇨 활성을 가지는 약용 식물에 관한 연구가 활발히 수행되고 있으며 $[12,17,35]$, 특히 당뇨병과 항산화 작용이 밀접한 관계가 있는 것으로 알려 지 면서 약용식물 추출물에 대한 항산화 및 항당뇨 연구가 활발 히 수행되고 있다[24, 34] 
당뇨병 치료에 효과가 있는 것으로 보고된 전통식물은 전 세계적으로 약 400여 종 이상으로 추정된다[14, 34]. 우리나라 에서 천연 항당뇨 물질에 대한 연구는 당뇨처방전에 사용되고 있는 당귀, 백복령, 상엽, 상백피, 총목피, 홍삼 등에 대한 항당 뇨 효과와, 최근에 큰방가지똥, 토후박 등의 추출물에서 항당 뇨 효과가 있는 것으로 보고되었으며 $[7,12,14]$, 해조류 중에서 는 모자반이 항당뇨 효과가 높은 것으로 보고되고 있다[17].

담쟁이덩굴(Parthenocissus tricuspidata)은 포도과에 속하는 낙엽덩굴식물로서 열대, 아열대 및 온대에 분포한다. 담쟁이 덩굴은 주로 돌담이나 바위 등에 붙어서 자생하지만 약으로 쓸 때는 반드시 나무를 감고 올라간 담쟁이덩굴을 사용하여야 한다. 민간요법에서는 줄기와 열매를 약으로 사용하는데 활 혈, 거풍, 진통작용, 어혈을 없애고 편두통, 류마티스성 관절염 등의 치료약으로 사용한다. 또한 당뇨병의 혈당치를 떨어뜨리 고 암이나 육종 치료에도 효과가 있는 것으로 알려져 있다[4].

Hwang 등[10]은 담쟁이덩굴에 대한 phenolic acid, flavonol, anthocyanin 및 hydroxybenzoic acid 에 대하여, Jeong과 Kim [11]은 담쟁이로부터 항산화물질을 연구하였으며, Wang 등 [33]은 담쟁이의 화학성분을 분석하였다. 그러나 담쟁이덩굴에 대한 항당뇨 활성에 대한 연구는 거의 없는 실정이다.

따라서 본 연구에서는 담쟁이덩굴의 열수 및 $80 \%$ 에탄올 추출물과 $80 \%$ 에탄올 추출물의 핵산 및 부탄올 추출물의 전자 공여능, SOD 활성, a-glucosidase 및 LAW 264.7 cell를 이용한 $\mathrm{NO}$ 활성과 MTT 분석을 통하여 당뇨병 치료에 이용할 수 있 는 neutraceuticals 소재로 활용하고자 본 연구를 수행하였다.

\section{재료 및 방법}

\section{시료조제}

본 실험에 사용한 담쟁이덩굴(P. tricuspidata)은 고려식품연 구원으로부터 구입하여 시료로 사용하였다. 건조시킨 당쟁이 덩굴을 $100 \mathrm{~g}$ 에 10 배의 용매를 가하여 추출하였다. 열수추출 물은 autoclave로 $100^{\circ} \mathrm{C}$ 에서 2시간씩 2회 추출하였으며, 에탄 올 추출물은 $80 \%$ 에탄올을 상온에서 24시간씩 shaking 하여 2 회 추출하였다. $80 \%$ 에탄올 추출물의 분획제조는 에탄올 추 출물을 물 $200 \mathrm{ml}$ 에 용해시켜 분액깔때기에 넣고 $200 \mathrm{ml}$ 의 n-hexane으로 3회 반복 추출하여 n-hexane 분획을 얻었으며, 이와 같은 방법으로 $\mathrm{n}$-butanol 분획을 얻었다. 추출물은 Whatman No. 2 filter paper로 여과한 후 rotary evaporator (EYELA N-1000, Rikakikai Co., Tokyo, Japan)로 농축하였다. 추출물들은 동결 건조하여 $-70^{\circ} \mathrm{C}$ 에서 보관하면서 본 실험에 사용하였다.

\section{폴리페놀 함량 측정}

총 polyphenol 함량은 Folin-Ciocalteu 법[29]을 약간 변형 시켜 측정하였으며 표준물질로서 tannic acid (Sigma
Chemical Co., USA)를 사용하여 계산하였다. 일정농도의 담 쟁이 추출물 $(1 \mathrm{mg} / 1 \mathrm{ml})$ 을 시험관에 취하고 Folin-Ciocalteu reagent $1 \mathrm{ml}$ 을 가하여 잘 혼합한 다음 3 분간 실온에서 반응시 켰다. 혼합물에 $10 \% \mathrm{Na}_{2} \mathrm{CO}_{3}$ 용액 $2 \mathrm{ml}$ 을 가하여 혼합하고 $30^{\circ} \mathrm{C}$ 에서 40 분간 발색시킨 후 $760 \mathrm{~nm}$ 에서 흡광도를 측정하였 다. 표준물질로 tannic acid의 최종농도가 $30,6090,120$ 및 $150 \mu \mathrm{g} / \mathrm{ml}$ 가 되도록 조절하여 위와 동일한 방법으로 측정한 표준곡선으로부터 담쟁이 추출물에 함유된 총 polyphenol 함 량 $(\mathrm{mg} / \mathrm{ml})$ 을 산출하였다.

\section{$\mathrm{DPPH}$ 라디칼 소거능 측정}

담쟁이 추출물의 전자공여능은 Blois의 방법[2]에 따라 1,1-Diphenyl-2-picrylhydrazyl (DPPH)에 대한 수소공여 효과 로 측정하였다. DPPH 용액은 $100 \mathrm{ml}$ 에탄올에 DPPH $1.5 \mathrm{x}$ $10^{4} \mathrm{M}$ 을 녹인 후 증류수 $100 \mathrm{ml}$ 혼합하여 Whatman filter paper No. 2로 여과하여 만들었다. 96 well plate에 시료와 $\mathrm{DPPH}$ 용액을 $1: 4$ 비율로 혼합하여 $37^{\circ} \mathrm{C}$ 에서 30 분간 반응시킨 후, ELISA reader를 이용하여 $520 \mathrm{~nm}$ (Molecular Device, VersaMax Microplate Reader, California, USA)에서 흡광도 를 측정하였다. 전자공여능(Electron donating ability, EDA) 은 $\mathrm{EDA}(\%)=($ 대조구흡광도-시료첨가구흡광도)/대조구흡광 도 $\times 100$ 으로 계산하였다. 시료를 첨가하지 않은 대조그룹과 흡 광도차를 비교하여 프리라디칼의 제거활성을 백분율로 나타 내었다.

\section{$\mathrm{SOD}$ 활성 측정}

Superoxide dismutase (SOD) 활성은 SOD assay kit (Dojindo Molecular Technologies, Rockville, USA)를 사용하 여 manufacturer's instruction에 기술된 방법에 따라서 수행 하였다. 시료를 농도별로 희석하여 96 well plate에 $20 \mu \mathrm{l}$ 씩 분주한 후, WST working solution을 $200 \mu 1$ 을 넣고 혼합한 다음 enzyme working solution을 $20 \mu 1$ 을 첨가하여 $37^{\circ} \mathrm{C}$ 에서 20 분간 incubation 한 후 $450 \mathrm{~nm}$ 에서 ELISA reader를 이용하 여 흡광도를 측정하였다. 대조구 실험은 효소 대신 $20 \mu \mathrm{ldilu}-$ tion buffer를 넣었으며, SOD 활성은 시료 첨가구와 무첨가구 사이의 흡광도 차이를 백분율 $(\%)$ 로 나타내었다.

SOD activity $(\%)=(1-$ 시료 첨가구의 흡광도/시료 무첨가구의 흡광도 $) \times 100$

\section{a-Glucosidase 활성억제 효과 측정}

a-Glucosidase 활성억제 효과 측정은 Tibbot 등의 방법[31] 에 따라 측정하였다. $50 \mathrm{mM}$ sodium succinate buffer $(\mathrm{pH}$ 4.2) 에 p-nitrophenol-a-D-glucopyranoside (PNPG, Sigma)를 용 해시켜 $1 \mathrm{mg} / \mathrm{ml}$ 의 농도로 기질용액을 조제하였다. 효소반응 은 기질용액 $1 \mathrm{ml}$ 와 효소액 $0.1 \mathrm{ml}$ (30 unit, Sigma)을 혼합하 고 대조구는 증류수 $0.1 \mathrm{ml}$, 반응구는 시료 $0.1 \mathrm{ml}$ 를 넣어 $37^{\circ} \mathrm{C}$ 
에서 30 분간 반응시킨 후 $1 \mathrm{~N} \mathrm{NaOH} 0.1 \mathrm{ml}$ 를 첨가하여 발색시 켰다. 이때 생성된 $\mathrm{p}$-nitrophenol (PNP)은 ELISA reader (VersaMax Microplate Reader)를 이용하여 $400 \mathrm{~nm}$ 에서 흡광 도를 측정하였으며, positive control로는 acarbose를 사용하였 다. a-Glucosidase 활성 저해율은 다음 식으로 계산하였다. 저해율 $(\%)=[1-($ 반응구의 $\rho$-nitrophenol 생성량/대조구의 $\rho$ -nitrophenol 생성량) $] \times 100$

\section{NO Assay 및 cell viability 측정}

$\mathrm{NO}$ 소거 활성은 마우스의 대식세포 세포주인 RAW 264.7 세포를 배양판에 $1 \times 10^{5} \mathrm{cells} / \mathrm{ml}$ 의 세포가 되도록 분주하여 LPS (lipopolysaccharide) 자극하에 24시간 배양하고 그 배양 상층액 내의 $\mathrm{NO}$ 의 생성은 Griess 반응으로 세포 상등액에 축 적되는 nitrite 양으로 측정하였다[22]. 시료에 대한 대조군으 로 $10 \mathrm{\mu g} / \mathrm{ml}$ 의 LPS를 처리하여 활성화를 유도한 세포를 사용 하였다. 배양 후 $100 \mu \mathrm{ll}$ 의 상층액을 취하여 동량의 Griess시약 [ $1 \%$ sulfanilamide ( $30 \%$ acetic acid)와 $0.1 \% \mathrm{~N}$-(1-naphthyl) ethylenediamine dihydrochloride $(60 \%$ acetic acid) 혼합액] 을 가하여 상온에서 20 분간 반응시킨 후 ELISA reader (Molecular Device, VersaMax Microplate Reader, California, USA)를 이용하여 $540 \mathrm{~nm}$ 에서 흡광도를 측정하였다.

세포독성 실험은 mitochondrial dehydrogenase activity의 index를 나타내는 MTT calorimetric reduction assay 법으로 추출물이 세포생존율에 미치는 영향을 측정하였다[22]. 96well microtiter plate (Nunc, Vangaard, Neptune, NJ)에 RAW 264.7 macrophage를 $1 \times 10^{5}$ cells/well의 농도로 분주하였다. 분주 24시간 후 각 추출물이 함유되어 있는 배지를 $100 \mu \mathrm{l}$ 씩 넣어 48 시간 동안 배양하였다.

Plate에 MTT 2 mg/ml 3-(4,5-dimethylthiazol-2-yl)-2,5-diphenyl-tetrazolium bromide (MTT, Sigma) 용액을 20 씨씩 첨 가하여 4시간 동안 배양시키고 formazan을 형성시킨 후 조심 스럽게 상등액을 제거하였다. DMSO 150 씨을 첨가하여 formazan을 녹인 후 ELISA reader (Molecular Device, VersaMax Microplate Reader, California, USA)를 이용하여 $570 \mathrm{~nm}$ 에서 흡광도를 측정하였다.

\section{결과 및 고찰}

\section{폴리페놀 함량 측정}

식물에는 항산화 비타민 이나 항산화활성을 가진 phytochemical들이 많이 함유되어 있다. 특히 약용식물에 널리 분포되어 있는 polyphenol성 화합물은 2 차대사산물로서 한분 자내에 2개 이상의 phenolic hydroxyl $(-\mathrm{OH})$ 기를 가진 방향족 화합물을 말한다. 식물에 존재하는 폴리페놀화합물은 항산화, 항돌연변이 및 phytoestrogen 효과 등의 다양한 생리활성을 가지고 있는 것으로 알려져 있다[8, 16]. 본 연구에서는 담쟁이
덩굴 열수 및 에탄올 추출물의 총 phenol 함량을 tannic acid 표준 곡선으로부터 측정하였다. 담쟁이덩굴의 열수 및 에탄올 추출물의 총 phenol 함량은 각각 $61.5 \mathrm{mg} \mathrm{TAE} / \mathrm{g}$ 과 $122.1 \mathrm{mg}$ $\mathrm{TAE} / \mathrm{g}$ 으로 에탄올 추출물에서 훨씬 높게 나타났다. 담쟁이덩 굴에 대한 페놀화합물에 대한 연구는 거의 없으며 Hwang 등 [10]이 당쟁이 덩굴 잎에서 플라보놀 배당체 화합물을 분리 동정하였다. Jeong 등[12]은 추출방법에 따른 총 페놀함량을 비교하였는데 약용식물에 따라 페놀함량이 다르게 나타났다. 당뇨처방에 사용되고 있는 약용식물 중 상백피에서 우리들의 실험결과와 유사하게 에탄올 추출물에서 페놀함량이 높게 나 타났다. Phenolic 화합물들은 지질 free radical 불활성화 및 hydroxy peroxide가 free radical로의 decomposition을 방해 함으로써 항산화력을 나타내는 매우 효과적인 free radical scavengers인 것으로 알려져 있다[23].

\section{$\mathrm{DPPH}$ 라디칼 소거능 측정}

인체내의 free radical은 지질, 단백질등과 반응하여 생체의 노화를 촉진할 수 있는 물질로, 이러한 free radical를 제거할 수 있는 천연물질에 대한 연구가 활발히 진행되고 있다. 특히 DPPH (1,1-diphenyl-2-picrylhydrazyl) radical 소거법은 항산 화물질의 전자공여능을 이용한 측정법으로 주로 pheonlic 구 조와 aromatic amine 화합물에서 많이 사용되는 방법이다. 담 쟁이덩굴의 항산화 효과를 DPPH radical 소거 활성으로 측정 한 결과(Fig. 1) $1 \mathrm{mg} / \mathrm{ml}$ 농도에서 열수 추출물, 에탄올, 핵산 층 및 부탄올층의 $\mathrm{DPPH}$ 라디칼 소거능은 약 $61 \%, 95 \%, 48 \%$ 및 $92 \%$ 로 각각 나타났다.

$\mathrm{DPPH}$ 용액은 실온에서 1시간 동안 안정한 radical을 형성 하기 때문에 전자 donation capacity 측정을 위해서 $\mathrm{DPPH}$ method가 널리 사용되고 있다. 식물추출물의 DPPH radical 에 대한 scavenging 활성은 phenolic content와 밀접한 관계가 있으며 특히 플라보노이드 보다는 폴리페놀 성분에 의해서 항산화 활성을 나타내는 것으로 알려져 있다[15].

\section{SOD 활성(Superoxide dismutase activity)}

Superoxide dismutase (SOD)는 항산화 효소로서 세포에 유 해한 oxygen radical을 과산화수소로 전환시키고, 다시 catalase에 의하여 무해한 물 분자와 산소분자로 전환시켜 활성산 소로부터 생체를 보호하는 기능으로 알려져 있다. 본 연구에 서 담쟁이 추출물의 SOD 활성은 $1 \mathrm{mg} / \mathrm{ml}$ 농도에서 열수 추 출물, 에탄올 및 핵산충은 약 $84 \%, 91 \%$, 및 $55 \%$ 로 각각 나타났 으며 부탄올층은 $0.5 \mathrm{mg} / \mathrm{ml}$ 에서 약 $93 \%$ 의 SOD 활성을 보였 다(Fig. 2). 이러한 결과는 담쟁이 부탄올층이 피부노화방지를 위한 천연소재로 이용가능성이 높은 것으로 사료된다. Superoxide dismutase는 산소를 소비하는 모든 생물종에 존 재하며 생체 내에서 발생되는 활성산소에 대한 방어 작용을 하는 대표적인 활성산소 저해제이다[9]. 또한 가장 독성이 강 
A

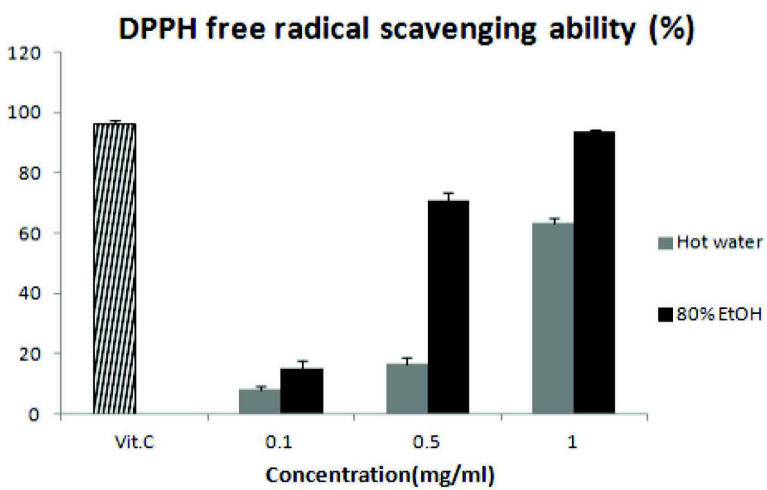

B

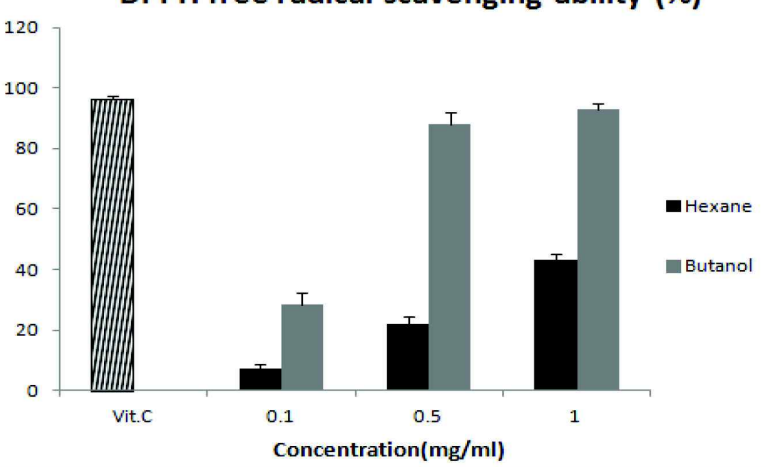

Fig. 1. DPPH free radical scavenging ability of hot water and $80 \%$ ethanol extracts $[\mathrm{A}]$, and hexane and butanol fractions [B] from Parthenocissus tricuspidata (PT) stem. Results are mean \pm S.D. of triplicate data. Vit C: vitamin C $(0.1 \mathrm{mg} / \mathrm{ml})$.

한 hydroxy radical의 생성을 예방하는 작용을 하여 항염증 소재나 피부 노화방지를 위한 소재로 사용되고 있다[18].

$\mathrm{SOD}$ 는 분자량이 비교적 큰 단백질로서 열이나 알칼리에 약하여 이러한 단점을 보완할 수 있는 저분자물질로 체내에서 역할이 유사한 SOD 유사활성 물질에 대한 연구가 진행되고 있다. SOD 유사활성 물질은 효소는 아니지만 SOD와 유사한 역할을 하는 저분자 물질로 주로 phytochemical에 속하며 superoxide의 반응성을 억제하여 항산화력을 나타내는 것으로 밝혀져 있다.

\section{$a-$ Glucosidase 활성억제 효과 측정}

a-Glucosidase는 a-amylase에 의해 분해된 당질을 최종적 으로 단당류로 전환시킨다. 이러한 효소의 활성 저해는 당질 가수분해와 흡수과정을 지연시킴으로 식후 당 농도를 제한한 다. 따라서 a-glucosidase 저해제는 제2형 당뇨와 같은 당질 관련 질병을 위한 치료제 개발에 유용하다.

본 연구에서 담쟁이 추출물의 a-glucosidase 저해 활성은 $1 \mathrm{mg} / \mathrm{ml}$ 농도에서 에탄올 추출물은 약 $96 \%$ 의 a-glucosidase 저해활성을 나타내었으며(Fig. 3A), 핵산층 및 부탄올층(Fig. $3 \mathrm{~B})$ 은 $0.1 \mathrm{mg} / \mathrm{ml}$ 농도에서 약 $90 \%$ 이상의 a-glucosidase 저해 활성을 나타내었다.
A

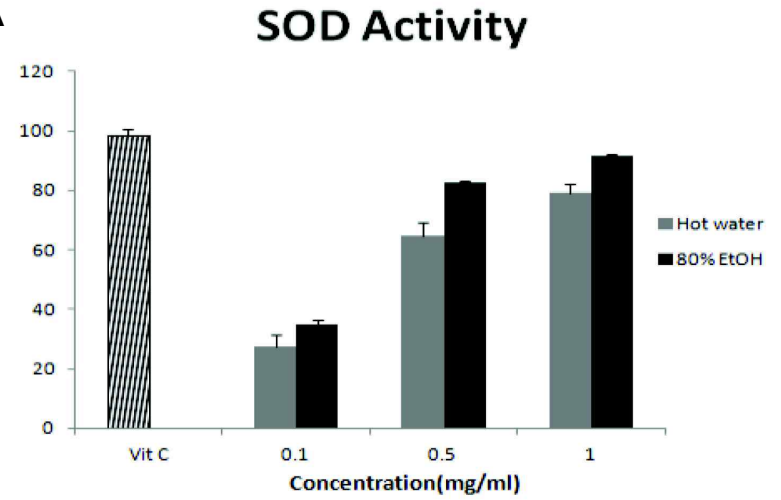

B

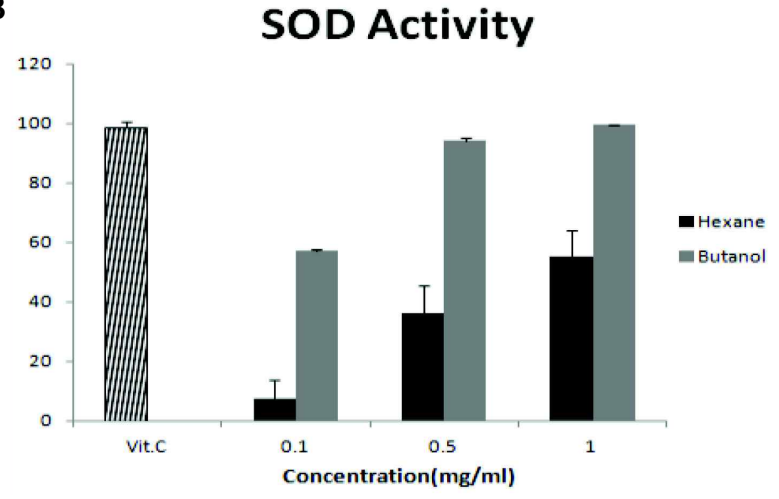

Fig. 2. Superoxide dismutase (SOD) activity of hot water and $80 \%$ ethanol extracts $[\mathrm{A}]$, and hexane and butanol fractions [B] from Parthenocissus tricuspidata (PT) stem. Results are mean \pm S.D. of triplicate data. Vit $C$ : vitamin C $(0.5 \mathrm{mg} / \mathrm{ml})$.

예로부터 항당뇨 효능이 있다고 알려져 당뇨병 처방전에 사용되고 있는 약용식물인 당귀, 백봉령, 상엽, 상백피, 총목피 및 홍삼등의 항당뇨활성[12]에 비해 담쟁이 추출물의 항당뇨 활성이 높게 나타났다. 현재 당뇨병 개선제로 시판되고 있는 acarbose $0.5 \mathrm{mg} / \mathrm{ml}$ 에서는 $40.4 \%$ 로 담쟁이 덩굴 추출물이 높 은 항당뇨활성을 나타내고 있다. 이러한 결과는 당쟁이 추출 물이 당뇨병 치료를 위한 천연소재로서의 이용가능성이 매우 높은 것으로 생각된다. Cho 등[6]의 선행연구에서 오미자 열 수 및 ethanol 추출물 $200 \mu \mathrm{g} / \mathrm{ml}$ 농도에서 a-glucosidase 활성 억제 효과는 각각 $97.4 \%$ 와 $84.5 \%$ 로 높게 나타나 항당뇨 개선 을 위한 천연소재로서의 활용도가 높은 것으로 사료된다.

식이 중에 함유된 탄수화물의 소화과정 마지막 단계를 촉매 하는 a-glucosidase는 포도당으로 전환시키는 효소로서 a -glucosidase 저해제는 탄수화물의 소화 흡수를 지연시켜 식 후 혈당증가를 완화시킨다. a-glucosidase 저해제는 비만을 야 기하는 고인슐린혈증이나 저혈당을 유발하지 않고, 인슐린 분 비를 촉진시키며 소장에서 글루카곤 분비를 억제하는 glucagon-like peptide-1의 분비를 촉진한다.

고혈당과 관련된 생화학적 대사과정에서 자유라디칼 생성 이 증가됨이 밝혀졌고, 그 밖에도 당뇨병에서는 조직의 산화 
A Alpha-glucosidase inhibitory activity(\%)

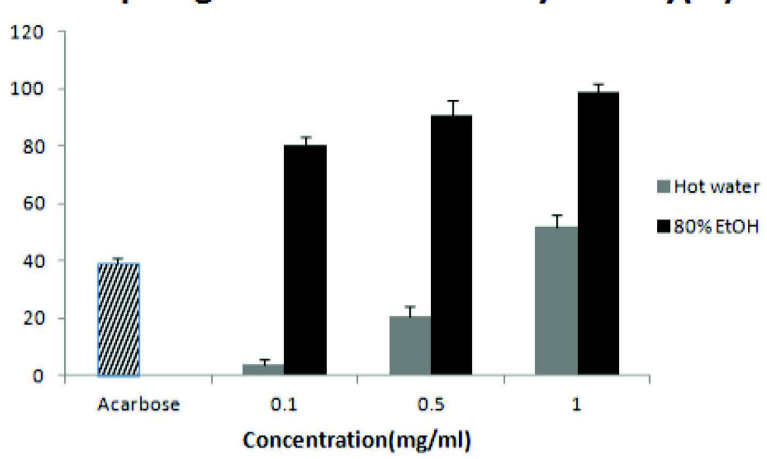

B

Alpha-glucosidase inhibitory activity(\%)

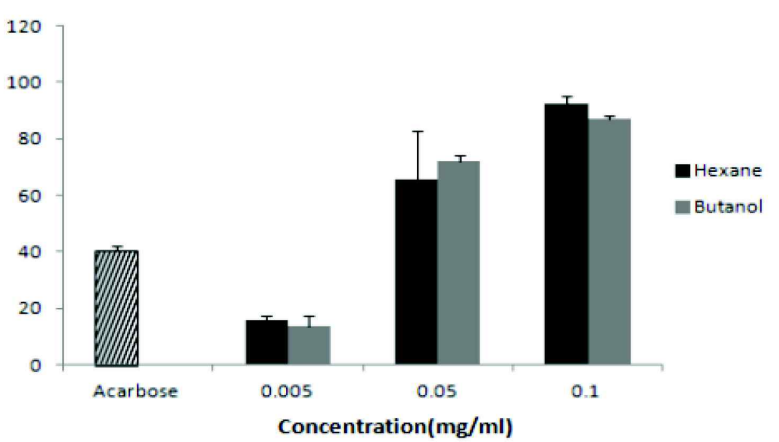

Fig. 3. a-Glucosidase inhibitory activity of hot water and $80 \%$ ethanol extracts $[\mathrm{A}]$, and hexane and butanol fractions [B] from Parthenocissus tricuspidata (PT) stem. Acarbose $(0.5 \mathrm{mg} / \mathrm{ml})$ was used as positive control. Results are mean \pm S.D. of triplicate data.

적손상이 증가될 수 있다. 이러한 산화적 손상을 막을 수 있는 mechanism은 항산화제에 의한 자유라디칼의 직접적인 소거 및 생체내 항산화효소에 의하여 활성산소 종을 불활성화 시키 는 것이다.

\section{NO Assay 및 cell viability}

대장균 lipopolysaccharide (LPS)를 대식세포에 처리하여 nitric oxide $(\mathrm{NO})$ 를 유도시킨 다음 담쟁이 열수 추출물을 대 식세포에 처리하여 NO 활성에 미치는 영향을 분석하였다 (Fig. 4). LPS에 의하여 유도된 대식세포의 NO 합성은 담쟁이 추출물의 농도가 증가할수록 감소하였고, 최대 농도인 1,000 $\mathrm{\mu g} / \mathrm{ml}$ 의 담쟁이 추출물을 처리함으로서 $60 \%$ 나 현저히 감소 시켰다. 이러한 결과는 담쟁이 추출물이 면역기능과 밀접한 관계가 있음을 보여주는 것이다.

$\mathrm{NO}$ 는 L-arginine의 guanidino nitrogen으로부터 nitric oxide synthase (NOS)에 의하여 생성되며[21], NO는 분비조직 과 세포의 기능에 영향을 미치며, 세포성 면역계의 주된 역할 의 하나로 세포 독성이나 성장 억제 작용을 한다.

체내 염증과정에서는 과량의 $\mathrm{NO}$ 및 prostaglandin $\mathrm{E}_{2}$ $\left(\mathrm{PGE}_{2}\right)$ 등의 염증인자가 $\mathrm{NO}$ synthase (iNOS) 및 cyclo-
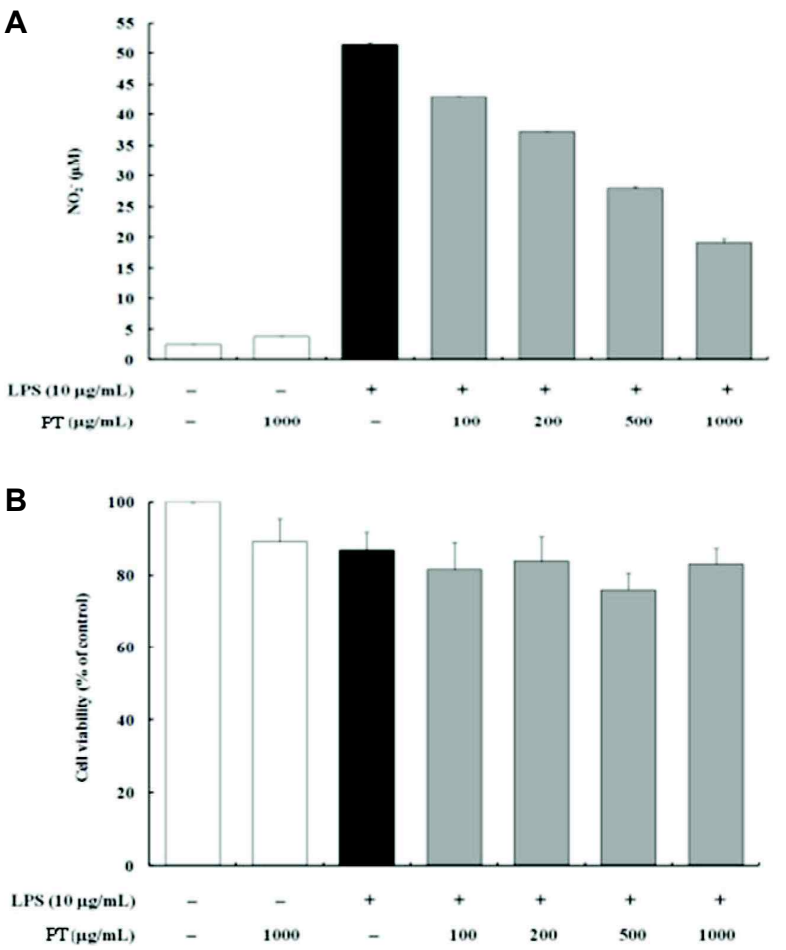

Fig. 4. Effects of hot water extract from Parthenocissus tricuspidata (PT) stem on NO synthesis [A] and cell viability [B] in bacterial LPS-stimulated RAW264.7 macrophages. RAW264.7 cells were cultured for $24 \mathrm{hr}$ with various concentration of PBE in the presence of LPS $(10 \mu \mathrm{g} / \mathrm{ml})$. NO release was measured using the method of Griess (nitrite). Cytotoxicity was determined by MTT assay. Results are presented as mean \pm S.D. of three independent experiments.

oxygenase (COX-2)에 의하여 대부분의 포유류 동물의 세포내 에서 형성된다[27]. 이러한 $\mathrm{NO}$ 는 체내방어기능, 신호전달기 능, 혈관계에서는 혈압 조절과 혈소판의 응집 및 호중성구의 집합 작용을, 골격근에서는 대사와 근 수축 조절 등의 다양한 생리 기능을 가지고 있다[28].

$\mathrm{NO}$ 가 발현하는 기능의 다양성은 농도 및 표적세포의 활성 화여부에 따라 달라진다고 알려져 있다. 대식세포가 pathogen 에 의하여 활성화되면 $\mathrm{NO}$ 뿐만 아니라 superoxide anion을 호흡과정에 의하여 대량생산되는데, $\mathrm{NO}$ 자신은 매우 약한 산 화성을 가진 라디칼로서 비타민 $\mathrm{E}$ 와 비슷하게 세포의 지질과 산화물을 막는 항산화 기능을 수행하는 것으로 알려져 있다.

일반적으로 $\mathrm{NO}$ 의 형성은 항균작용 및 종양을 제거하는 중 요한 기능을 하지만 병리학적인 원인에 의한 과도한 $\mathrm{NO}$ 의 생성은 염증을 유발시키게 되며, 조직의 손상, 유전자 변이 및 신경손상 등을 유발한다[25].

세포독성실험은 MTT 분석을 통해서 측정하였으며 담쟁이 추출물로 처리된 대식세포의 세포생존율이 $90 \%$ 정도를 나타 내는 바 본 연구에서 사용된 담쟁이덩굴 추출물에 대한 세포 
독성은 없는 것으로 관찰되었다. 또한, 실험결과에 나타난 $\mathrm{NO}$ 의 생성량의 변화가 세포독성에 의한 영향과는 무관함을 확인 할 수 있었다.

\section{References}

1. Anoja, S. A., Zhou, Y. P., Xie, J. T., Wu, J. A., Zhang, L., Dey, L., Pugh, W., Rue, P. A., Polonsky, K. S. and Yuan, C. S. 2002. Antidiabetic effect of Panax ginseng berry extract and the identification of an effective component. Diabetes 51, 1851-1858.

2. Blois, M. S. 1958. Antioxidant determination by the use of a stable free radical. Nature 26, 1198-1200.

3. Braunwald, E., Fauci, A. S., Kasper, D. L., Hause, S. L., Longo, D. L. and Jameson, J. L. 2011. Harison's Principles of Internal Medicine. 15th ed, McGraw-Hill, New York, NY, USA. pp. 2109-2137.

4. Cao, L. H. 2004. Studies on the anticancer constituents with cytotoxic and topoisomerase inhibitory activity from the stems of Parthenocissus tricuspidata. Ph. D. Thesis, Catholic University, Daegu, Korea.

5. Cha, M. R., Park, J. H., Choi, Y. H., Choi, C. W., Hong, K. S., Choi, S. U., Kim, Y. S., Kim, Y. K., Kim, Y. H. and Ryu, S. Y. 2009. Alpha-glucosidase inhibitors from the branches extract of Continus coggygria. Korean J Pharmacogn 40, 229-232.

6. Cho, H. E., Choi, Y. J. and Cho, E. K. 2010. Antioxidant and nitrite scavening activity and a-Glucosidase inhibitory effect of water extract from Schizondra chinesis Baillon. $J$ Korean Soc Food Sci Nutr 39, 481-486.

7. Choi, W. S., Lee, S. E., Lee, H. S., Lee, Y. H. and Park, B. S. 1998. Antioxidative activities of methanol extracts of tropical and oriental medicinal plants. Agric Chem Biol 41, 556-559.

8. Choi, S. Y., Lin, S. H., Ha, T. Y., Kim, S. R., Kang, K. S. and Hwang, I. K. 2005. Evaluation of the estrogenic and antioxidant activity of some edible and medical plant. Korean J Food Sci Technol 37, 549-556.

9. Greenstock, C. L. 1993. Radiation and aging: free radical damage, biological response and possible antioxidant intervention. Med Hypothesis 41, 473-478.

10. Hwang, H. K., Sung, H. K., Whang, W. K. and Kim, I. H. 1995. Flavonoid glycosides from Parthenocissus tricuspidata leaves. Yakhak Hoechi 39, 289-296.

11. Jeong, H. J. and Kim, C. H. 2001. Screening of the antioxidant defense systems from Parthenocis년 tricuspidata PLANCH. Korean J Plant Res 14, 116-123.

12. Jeong, H.-J., Lee, S. G., Lee, E.-J., Park, W.-D., Kim, J.-B. and Kim, H.-J. 2010. Antioxidant activity and anti-hyperglycemic activity of medicinal herbal extracts according to extraction methods. Korean J Food Sci Technol 42, 571-577.

13. Jeong, I.-K., Chung, J.-H., Min, Y.-K., Lee, M.-S., Lee, M.-K., Kim, K.-W., Joong, Y.-E., Park, J.-Y., Hong, S.-K. and Lee, K.-U. 2002. Comparative study about effects of acarbose and voglibose in type-2 diabetic patients. J Korean Diabetes 26,
134-145.

14. Kim, D. H., Kang, Y. G., Kim, H. and Chae, H. J. 2004. Investigation of antidiabetic medicinal plants using an oriental medicinal database. Korean J Biotechnol Bioeng 19, 125-131.

15. Kim, H. K., Kim, G. T., Ryu, J., Choi, J. S. and Choi Y. G. 1995. Antioxidative activity and physiological activity of some Korean medicinal plants. J Food Sci Nutr 33, 621-625.

16. Lee, J. H. and Lee, S. R. 1994. Analysis of phenolic substances content in Korean plant food. Chem Pham Bull 26, 310-316

17. Lee, E. H., Ham, J., Ahn, H. R., Kim, M. C., Kim, C. Y., Pan, C.-H., Um, B. H. and Jung, S. H. 2009. Inhibitory effects of the compounds isolated from Sargassum yezoense on a-glucosidase and oxidative stress. Korean J Pharmacogn 40, 150-154.

18. Lee, J.-Y. and An, B.-J. 2012. Antioxidant and anti-inflammatory effects of fractions from Pruni persicae flos. Korean J Herbology 27, 55-63.

19. Lee, K. W., Shon, B. H., Kang, S. K., Park, D. H., Min, B. S. and Song, H. Y. 1984. Epidemiologic study for diabetes in 1821 Koreans. Diabetes 8, 5-14.

20. Li, M. and Shah, A. M. 2003. ROS generation by nonphagocytic NADPH oxidase : potential relevance in diabetic nephropathy. J Am Soc Nephrol 14, S 221-226.

21. Lugnier, C., Keravis, T. and Eckly-Michel, A. 1999 Cross talk between $\mathrm{NO}$ and cyclic nucleotide phosphodiesterases in the modulation of signal transduction in blood vessel. $J$ Physiol Pharmacol 50, 639-652.

22. Marletta, M. A. 1993. Nitric oxide synthase structure and mechanism. J Biol Chem 268, 12231-12234.

23. Masuthisakul, P., Suttajit, M. and Pongsawatmanit, P. 2007. Assessment of phenolic content and free radical-scavenging capacity of some Thai indigenous plants. Food Chem 100, 1409-1418.

24. Matough, F. A., Budin, S. B., Hamid, Z. A., Alwahaibi, N. and Mohamed, J. 2012. The role of oxidative stress and antioxidant in diabetic complications. Squ Med J 12, 5-18.

25. McCartney-Francis, N., Allen, J. B., Mizel, D. E., Albina, J. E., Xie, Q. W., Nathan, C. F. and Wahl, C. F. 1993. Suppression of arthritis by an inhibitor of nitric oxide synthase. J Exp Med 178, 749-754.

26. Mohanty, P., Hamouda, W., Garg, R., Aljada, A., Ghanim, H. and Dandona, P. 2000. Glucose challenge stimulates reactive oxygen species (ROS) generation by leukocytes. J Clin Endocrinol Metab 85, 2970-2973.

27. Moncada, S., Palmer, R. M. and Higgs, E. A. 1991. Nitric oxide: physiology, pathophysiology, and phamracology. Pharmacol Rev 43, 109-142.

28. Nathan, C. 1992. Nitric oxide as a secretory product of mammalian cells. FASEB J 6, 3051-3064.

29. Sakai, K., Matsumoto, K., Nishikawa, T., Suefuji, M., Nakamura, Y., Shirotami, T., Ichinose, K., Brownlee, M. and Araki, E. 2003. Mitochondrial reactive oxygen species reduce insulin secretion by pancreatic beta-cells. Biochem Biophysics Res Commun 300, 216-222.

30. Singleton, V. L. and Rossi, J. A. 1965. Colorimetry of total 
phenolic with phosphomolybdic-phosphotungsuic acid reagents. Am J Enol Vitic 16, 144-158.

31. Tibbot, B. K. and Skadsen, R. W. 1996. Molecular cloning and characterization of a gibberellin-inducible, putative a-glucosidase gene from berley. Plant Mol Biol 30, 229-241.

32. Tsujimoto, T., Shioyama, E., Moriya, K., Kawaratani, H., Shirai, Y., Toyohara, M., Mitoro, A., Yamao, J., Fujii, H. and Fukui, H. 2008. Pneumatosis cytosides intestinalis following alpha-glucosidase inhibitor treatment: a case report and review of the literature. World J Gastroenterol 14, 6087-6092.

33. Wang, Y. F., Zhang, Ch. G., Yao, R. R. and Zhou, W. S.
1982. Studies on chemical constituents of Parthenocissus tricuspidata planch. Yao Xue Xue Bao 17, 466-468.

34. Xu, M.-L., Wang, L., Xu, G.-F. and Wang, M.-H. 2011. Antidiabetes and angiotensin converting enzyme inhibitory activity of Sonchus asper (L) Hill extract. Korean J Pharmacogn $42,61-67$.

35. Xu, M.-L., Hu, J. H., Wang, L., Kim, H. S. Jin, C. W. and Cho, D. H. 2010. Antioxidant and anti-diabetes activity of extracts from Machilus thunbergii S. et Z. Korean J Medicinal Crop Sci 18, 34-39.

\section{초록 : 담쟁이덩굴 추출물과 분획물의 항산화, 항당뇨 및 항염증 효과}

\section{조은경·최영주*}

(신라대학교 의생명과학대학 식품영양학과)

본 연구에서는 담쟁이덩굴 추출물이 항산화, 항당뇨 및 항염증 효과에 미치는 영향을 조사하고자 수행하였다. 담쟁이덩굴 열수 및 에탄올 추출물의 총 페놀함량은 각각 $61.5 \mathrm{mg} \mathrm{TAE} / \mathrm{g}$ 과 $122.1 \mathrm{mg} \mathrm{TAE} / \mathrm{g}$ 으로 에탄올 추출물 에서 훨씬 높게 나타났다. 에탄올 추출물과 부탄올 분획물의 DPPH 라디칼 소거활성은 $1 \mathrm{mg} / \mathrm{ml}$ 에서 $95 \%$ 와 $92 \%$ 의 radical 소거능을 나타내어 positive control로 사용한 비타민 C와 유사한 항산화력을 보였다. SOD 활성은 에 탄올 추출물과 부탄올 분획물 $1 \mathrm{mg} / \mathrm{ml}$ 농도에서 $91 \%, 97 \%$ 로 높은 활성을 나타내었다. DPPH radical 소거능과 $\mathrm{SOD}$ 활성을 측정한 결과 항산화 활성은 모두 농도 의존적으로 증가하였으며 특히 열수추출물과 비교할 때 에탄 올 추출물과 부탄올 분획물에서 높은 항산화 효과를 보였다. 담쟁이덩굴 추출물의 a-glucosidase 활성억제 효과 는 에탄올 추출물과 핵산 및 부탄올 분획층에서 높은 항당뇨 효과를 나타내었다. 이러한 결과는 지금까지 항당뇨 약물로 사용된 것보다도 높은 것으로 나타났다. LPS에 의하여 유도된 NO 합성은 $1 \mathrm{mg} / \mathrm{ml}$ 농도의 담쟁이추출물 을 처리함으로써 NO 합성이 약 $40 \%$ 로 감소하였다. 이러한 결과들은 담쟁이 추출물의 우수한 항산화, 항당뇨, 항염 효과를 시사하고 있으며 특히, 천연 항당뇨 기능성 소재로서 담쟁이 추출물의 활용 가능성이 높을 것으로 사료된다. 